\title{
Clinical uses and control of rifampicin and clindamycin
}

\author{
IAN PHILLIPS
}

From the Department of Clinical Microbiology, Louis Jenner Laboratories, St Thomas's Hospital, London

At first sight, rifampicin and clindamycin may appear to have little in common: the former is best known as a potent antimycobacterial drug while the main use of the latter is in treating infections due to staphylococci and streptococci. However, they can with justification both be placed in the late Professor Mary Barber's group I of antibacterial agents that have activity against Gram-positive organisms and Gram-negative cocci (Barber, 1966). It is mainly with these aspects that the present paper is concerned, although the activity of rifampicin against Gram-negative bacilli will also be discussed.

\section{Pharmacological Properties}

\section{RIFAMPICIN}

Rifampicin is a semisynthetic derivative of rifamycin B, one of five rifamycins isolated from Streptomyces mediterranei (Sensi, 1969). These compounds have a unique structure among antibiotics, consisting of an aliphatic bridge spanning a chromophoric naphthohydroquinone group. Rifampicin acts by inhibiting DNA-dependent RNA polymerase, thus stopping the expression of bacterial genes (Hartmann, Honikel, Knüsel, and Nüesch, 1967; Furesz, 1969). This action is bactericidal.

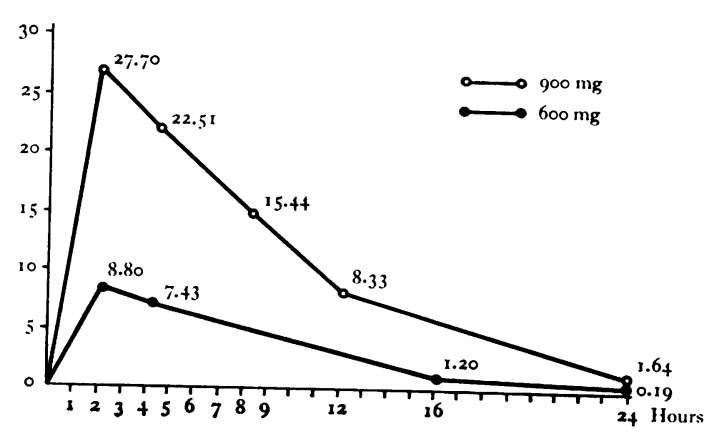

Fig. 1 Serum levels of rifampicin after oral doses of $600 \mathrm{mg}$ and $900 \mathrm{mg}$.
The pharmacological properties of rifampicino have been reviewed by Jouhar (1968) who gives many? references to earlier Italian work. The antibiotic is well absorbed from the gut, but peak levels areir diminished if the antibiotic is given after food $\vec{A}$ Figure 1 (modified from Furesz, Scotti, Pallanza and Mapelli, 1967) shows mean serum levels produced after doses of $600 \mathrm{mg}$ and $900 \mathrm{mg}$. There is considerable individual variation in peak levels (Verbist, 1969) but useful concentrations persist for more than 12 hours. On this basis a daily dose of about $10 \mathrm{mg}$ per kilogram is recommended. In the case of tuberculosis, this is usually given as a single dose, but for acute infections it is probably bes divided, and a dose of $300 \mathrm{mg}$ to $450 \mathrm{mg}$ twice daily would be suitable for most adults. Doses of up to $30 \mathrm{mg}$ per kilogram have been given daily as a single dose without harm. It is a disadvantage that parenteral preparation is not available for the treat $\frac{0}{3}$ ment of seriously ill patients.

A microbiologically active desacetyl metabolie derivative is excreted in the bile along with the parent compound. The latter is reabsorbed from the gut resulting in an enterohepatic recirculation whicks maintains blood levels but desacetylrifampicin is largely not reabsorbed (Curci, Ninni, and Iodice? 1969). Excretion by the liver competes with brom $?$ sulphthalein, and falsely high BSP retention result $\rho$ if hepatic function is assessed by this method in patients receiving rifampicin.

Concentrations in bile reach levels above $15 \overline{\mathrm{a}}$ $\mu \mathrm{g} / \mathrm{ml}$ and a plateau is attained with doses above about $300 \mathrm{mg}$, as is shown in Figure 2 (based on results of Acocella, Nicolis, and Lamarina, 1967) Bile levels are not nearly as high as those of rifamide which is rapidly and almost exclusively excreted bob this route, producing concentrations of the order of $1,000 \mu \mathrm{g} / \mathrm{ml}$. Unlike rifamide, rifampicin is excrete $\$$ in the urine, in increasing amounts when the biliaryo route is saturated, that is, with doses in excess of about $300 \mathrm{mg}$ (Figure 2). About $25 \%$ of a $600 \mathrm{mg}$ dose is excreted in an active form in the urine in $2 \Phi$ hours, producing concentrations above $100 \mu \mathrm{g} / \mathrm{m}$ for more than 12 hours. 


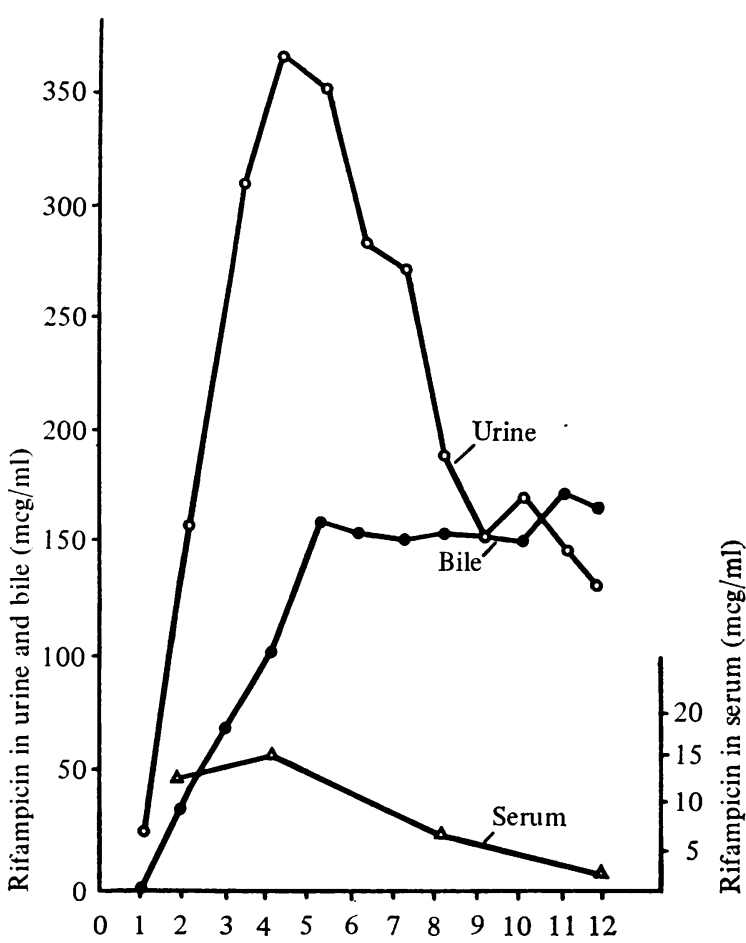

Hours after administration

Rifampicin is $85 \%$ bound to serum proteins but of the unbound fraction most is non-ionized and therefore free to diffuse more easily into the tissues (Curci et al, 1969). However, levels in cerebrospinal fluid are only $15 \%$ of serum levels even when the meninges are inflamed, as are levels in pleural exudate and ascitic fluid (Furesz et al, 1967). The drug crosses the placenta.

Both hepatocellular disease and biliary obstruction impede excretion: the half-life of rifampicin in the serum of patients with complete obstruction is about three to four times normal. Serum levels should be monitored if the drug is to be used in patients with these conditions. On the other hand renal failure has little effect on blood levels (Spring, 1968), but little is known of the fate of microbiologically inactive metabolites, and, although toxicity has not been observed, the drug should be used with caution in patients with renal failure. Rifampicin levels are not significantly affected by either peritoneal dialysis or haemodialysis (Spring, 1968).

In a recent editorial that considers over 100 reports of the clinical use of rifampicin, the Lancet (1969) concludes that it is 'remarkably free from
Fig. 2 Rifampicin levels in serum, bile, and urine after a single oral dose of $450 \mathrm{mg}$. toxicity'. In a very few patients, most of them receiving other drugs in addition for the treatment of tuberculosis, serious but reversible liver damage has resulted, with raised alkaline phosphatase and transaminase levels. Many of these patients probably had preexisting liver disease. A solitary, transient rise in serum bilirubin is commoner but of less sinister significance, and probably results from competition for excretion. Because rifampicin has been shown to be teratogenic in rats and mice given the equivalent of 10 times the human dose, it should be used during pregnancy only when absolutely necessary.

Among more minor side effects reported have been reversible leucopenia, eosinophilia, rashes, and diarrhoea. Patients should be warned that rifampicin may colour urine, sputum, and tears various shades of orange.

\section{CLINDAMYCIN}

There is still confusion in the nomenclature of this drug. The British Medical Association's recently published booklet 'Today's Drugs' (1970) follows earlier American usage and refers to the drug as clinimycin. Unfortunately, a recent brand of oxytetracycline has 
the proprietary name Clinimycin. The approved name, in Britain, of the drug to be discussed is clindamycin.

Clindamycin is 7-chloro-7-deoxylincomycin, a semi-synthetic derivative of lincomycin which is isolated from Streptomyces lincolnensis. It was one of a number of derivatives investigated for better absorption, higher activity, and a broader spectrum than lincomycin itself (Magerlein, Birkenmeyer, and Kagan, 1966). The lincomycins, like erythromycin, bind to the 50S ribosomal subunit, inhibit the binding of aminoacyl transfer RNA to nascent polypeptides, and therefore stop protein synthesis (Weisblum and Davies, 1968). This action is bacterostatic at low concentrations but bactericidal at slightly higher ones.

Figure 3, based on the results of McGehee, Smith, Wilcox, and Finland (1968), which are similar to those of Wagner, Novak, Patel, Chidester, and Lummis (1968), shows serum levels reached after oral doses of $500 \mathrm{mg}$ of lincomycin and $500 \mathrm{mg}$ clindamycin taken before and after food. Levels of clindamycin are considerably higher and are not significantly affected by food. Doses of $150 \mathrm{mg}$ to

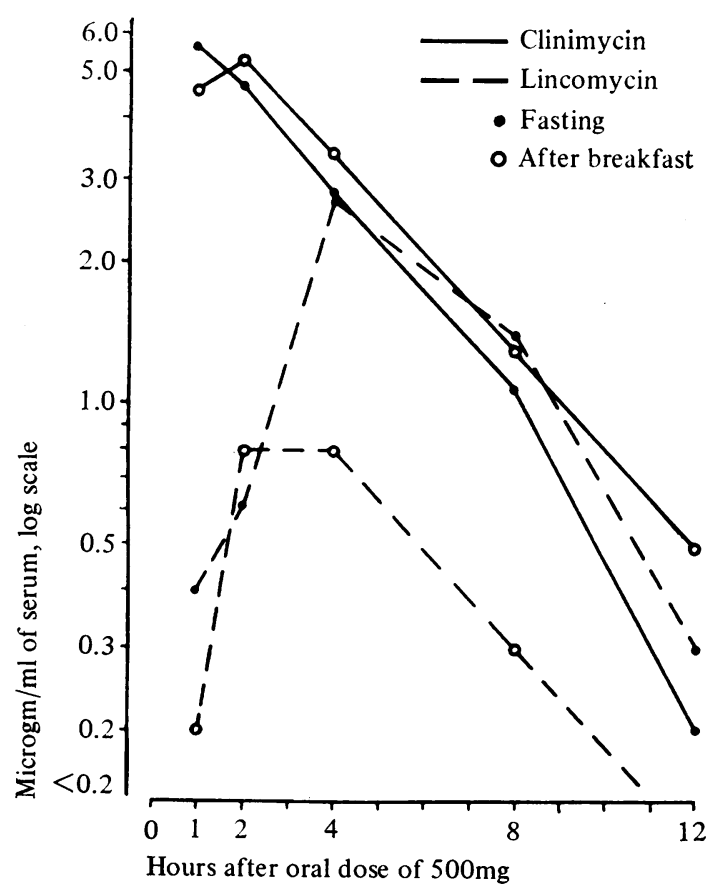

Fig. 3 Serum levels of clindamycin and lincomycin after oral doses of $500 \mathrm{mg}$ of the two drugs before and after a meal.
$450 \mathrm{mg}$ clindamycin four times daily are recom- $\stackrel{\stackrel{0}{\circ}}{\circ}$ mended, the exact dose depending on the severity of $\cdot$ the disease. Again, no parenteral preparation is available and lincomycin has to be substituted if injections are required.

An active demethyl derivative has been detected $\frac{\overline{\bar{N}}}{\overline{2}}$ in serum (Brodasky, Argoudelis, and Eble, 1968) $\overrightarrow{\mathbb{D}}$ but the major metabolic pathways in man are not established. Using radioactive labelling some $60 \%$ of the drug and its metabolites can be recovered from $\overrightarrow{0}$ faeces in animals (Sun, 1970). There is evidence of moderate concentration in bile, and about one eighth $\vec{\omega}$ of the activity appears in the urine in 24 hours, considerably more than with lincomycin.

The degree of protein binding of clindamycin varies with the method of determination, but is probably low. Like the parent compound it is known $\stackrel{\oplus}{\circ}$ to give high levels in bone and to cross into the ${ }_{\odot}$ cerebrospinal fluid in meningitis but not in the normal subject.

Cimino and Tierno (1969) have reported that anuria prolongs the half-life of clindamycin onlymoderately, and that only minor modification of dosage is needed in renal failure. Levels are not affected by haemodialysis. In an anephric patient whom we investigated recently, with a dose of 150 s mg four times daily used to treat pneumococcalo pneumonia and bacteraemia, peak levels varied $\varrho$ between $3 \mu \mathrm{g} / \mathrm{ml}$ and $3.8 \mu \mathrm{g} / \mathrm{ml}$-not much above $\stackrel{\mathbb{Q}}{\mathscr{Q}}$ normal-but five hours after a dose levels varied $\vec{F}$ between $1.8 \mu \mathrm{g} / \mathrm{ml}$ and $2.5 \mu \mathrm{g} / \mathrm{ml}$. Information on $\frac{O}{3}$ the effect of biliary obstruction and liver disease is $?$ lacking, but as the major excretion route is probably? via the liver, clindamycin should be used with caution in these conditions.

Like lincomycin, clindamycin has few toxic effects. $\frac{\overline{3}}{3}$ Impaired bilirubin excretion has been reported, $\stackrel{3}{\circ}$ particularly among those with liver disease, as have $\bigcirc$ transient rises in SGPT in apparently normal individuals. Mild diarrhoea is not uncommon, but 을 is said to be much less troublesome than that follow- $D$ ing lincomycin. Skin rashes are relatively common according to one report (Geddes, Bridgwater, $\bar{N}$ Williams, Oon, and Grimshaw, 1970) and eosino-philia has occasionally been seen.

\section{Microbiological Assay}

RIFAMPICIN

Procedures are described for the filter-paper disc $\stackrel{\mathscr{D}}{+}$ method and the cup-plate or well method, using $?$ Sarcina lutea ATCC 9341 (Staphylococcus lactis, NCTC 8340) as the assay organism. We have found $\stackrel{\circ}{\circ}$ Sarcina to be more suitable than Bacillus subtilis $\stackrel{\mathbb{Q}}{\circ}$ which appears to be not sufficiently sensitive. The $\bar{O}$ recommended assay medium is Difco Penassay seed 
agar (Bacto-Antibiotic medium 1) with $3 \mathrm{ml}$ M. $\mathrm{KH}_{2} \mathrm{PO}_{4}(p \mathrm{H} \mathrm{4 \cdot 2})$ added to each $100 \mathrm{ml}$. Rifampicin standard solutions, which are stable for several weeks at $4^{\circ} \mathrm{C}$, can be made by dissolving $1,000 \mu \mathrm{g} / \mathrm{ml}$ rifampicin in $20 \%$ methanol in $p H 7$ phosphate buffer, or if higher concentrations are needed, $10,000 \mu \mathrm{g} / \mathrm{ml}$ rifampicin in dimethylformamide. Serial dilutions of this stock solution over the required range should be made in serum, if serum levels are to be assayed, or in $p \mathrm{H} 7$ buffer for urine. It appears that the linear portion of the standard curve lies below $10 \mu \mathrm{g} / \mathrm{ml}$ in the well method. Sera and other fluids will often need to be diluted for assay for this reason.

\section{CLINDAMYCIN}

Again procedures are described for the filter-paper disc and well methods using Sarcina lutea ATCC 9341 (Staphylococcus lactis, NCTC 8340) as the assay organism and Difco Penassay seed agar (Bacto-Antibiotic medium 1). Clindamycin stock solutions, stable at $4^{\circ} \mathrm{C}$ for at least two weeks, are made by dissolving powder of known potency in distilled water or $\mathbf{O} \cdot \mathrm{IM}$ phosphate buffer $p \mathbf{H ~ 8}$, to a concentration of $1,000 \mu \mathrm{g} / \mathrm{ml}$. This solution is diluted in serum to give a series of standards over a range from about 10 to $0.2 \mu \mathrm{g} / \mathrm{ml}$. Serum can usually be assayed undiluted.

\section{Sensitivity Testing in vitro}

\section{RIFAMPICIN}

It has been suggested that there is poor correlation between zone sizes around antibiotic-containing discs and minimal inhibitary concentrations (MICs) determined in liquid or on solid media (McCabe and Lorian, 1968). However, as a rough screen, disc testing is probably worthwhile: in our laboratory,

\begin{tabular}{|c|c|c|c|c|c|c|c|c|c|c|c|c|c|c|c|c|c|}
\hline \multirow[t]{2}{*}{ Organism } & \multirow[t]{2}{*}{ Antibiotic ${ }^{1}$} & \multirow{2}{*}{$\begin{array}{l}\text { No. of } \\
\text { Strains }\end{array}$} & \multicolumn{15}{|c|}{ Percentage Strains with MIC $(\mu \mathrm{g} / \mathrm{ml})$} \\
\hline & & & 0.003 & 0.007 & 0.015 & 0.03 & 0.06 & $0 \cdot 12$ & 0.25 & 0.5 & 1 & 2 & 4 & 8 & 16 & 32 & $>32$ \\
\hline Staph.aureus & $\begin{array}{l}\mathbf{R} \\
\mathbf{C} \\
\mathbf{L} \\
\mathbf{E}\end{array}$ & 243 & $\frac{6}{-}$ & $\begin{array}{l}\frac{60}{-} \\
-\end{array}$ & $\begin{array}{l}27 \\
- \\
-\end{array}$ & $\frac{6}{\frac{3}{-}}$ & $\begin{array}{l}\overline{90} \\
-\end{array}$ & $\begin{array}{r}- \\
2 \\
3\end{array}$ & $\begin{array}{l}\overline{-} \\
\overline{11} \\
26\end{array}$ & $\frac{-}{39}$ & $\frac{-}{43}$ & $\frac{-}{4}$ & $\begin{array}{l}E \\
z\end{array}$ & $\begin{array}{l}0.5 \\
=\end{array}$ & $\bar{z}$ & $\frac{z}{z}$ & $\begin{array}{c}0.5 \\
1 \\
1 \\
56 \\
\uparrow R\end{array}$ \\
\hline Beta-haemolytic streptococci & $\begin{array}{l}\mathbf{R} \\
\mathbf{C} \\
\mathbf{E} \\
\mathbf{L}\end{array}$ & 43 & $\begin{array}{l}\overline{-} \\
\overline{-}\end{array}$ & $\begin{array}{l}E \\
z\end{array}$ & $\frac{18}{-}$ & $\frac{18}{-}$ & $\begin{array}{l}22 \\
47 \\
-\end{array}$ & $\begin{array}{r}30 \\
49 \\
47 \\
1\end{array}$ & $\begin{array}{r}10 \\
4 \\
44 \\
55\end{array}$ & $\begin{array}{r}2 \\
9 \\
40\end{array}$ & $\frac{-}{2}$ & $\frac{-}{2}$ & $=$ & $\bar{z}$ & $\bar{z}$ & $\begin{array}{l}- \\
z\end{array}$ & $\bar{z}$ \\
\hline Str. viridans and Str.pneumoniae & $\begin{array}{l}\mathbf{C} \\
\mathbf{E} \\
\mathbf{R} \\
\mathbf{L}\end{array}$ & $\begin{array}{l}52 \\
52 \\
25 \\
52\end{array}$ & $\begin{array}{l}\bar{Z} \\
-\end{array}$ & $\frac{-}{4}$ & $\frac{40}{\frac{40}{4}}$ & $\begin{array}{l}42 \\
79 \\
24 \\
-\end{array}$ & $\begin{array}{l}18 \\
11 \cdot 5 \\
44 \\
-\end{array}$ & $\begin{array}{c}\overline{7 \cdot 5} \\
4 \\
25\end{array}$ & $\frac{\overline{2}}{46}$ & $\bar{z}$ & $\frac{-}{8}$ & $\begin{array}{l}\overline{-} \\
\overline{-}\end{array}$ & $\begin{array}{l}z \\
z\end{array}$ & $\begin{array}{l}\overline{-} \\
\overline{-}\end{array}$ & $\frac{-}{z}$ & $\bar{z}$ & $\bar{z}$ \\
\hline Str. faecalis & $\begin{array}{l}\mathbf{R} \\
\mathbf{E} \\
\mathbf{C} \\
\mathbf{L}\end{array}$ & $\begin{array}{l}10 \\
12 \\
12 \\
12\end{array}$ & $\bar{z}$ & $\bar{E}$ & $\frac{1}{E}$ & $\bar{z}$ & $\begin{array}{l}\overline{-} \\
\overline{-}\end{array}$ & $\bar{z}$ & $\begin{array}{l}- \\
-\end{array}$ & $\frac{-}{-}$ & E & $\begin{array}{l}30 \\
\frac{17}{\uparrow}\end{array}$ & $\begin{array}{r}20 \\
23 \\
8 \\
-\end{array}$ & $\begin{array}{l}10 \\
25 \\
-\end{array}$ & $\begin{array}{l}10 \\
17 \\
-\end{array}$ & $\frac{30}{-}$ & $\frac{-}{92}$ \\
\hline Cl. welchii & $\begin{array}{l}\mathbf{R} \\
\mathbf{C} \\
\mathbf{L} \\
\mathbf{E}\end{array}$ & 14 & $\frac{\bar{Z}}{\overline{43}}$ & $\frac{-}{57}$ & $\begin{array}{l}\bar{Z} \\
-\end{array}$ & $\frac{71}{-}$ & $\begin{array}{l}\bar{Z} \\
\overline{-}\end{array}$ & $\overline{\bar{I}}$ & $\begin{array}{l}\overline{71} \\
-\end{array}$ & $\frac{14 \cdot 5}{7}$ & $\frac{14 \cdot 5}{86}$ & $\frac{-}{7}$ & $\begin{array}{l}\overline{29} \\
-\end{array}$ & $\frac{-}{-}$ & $\frac{-}{-}$ & $\frac{-}{-}$ & $\bar{z}$ \\
\hline Neisseria gonorrhoeae & $\begin{array}{l}\mathbf{E} \\
\mathbf{R} \\
\mathbf{C} \\
\mathbf{L}\end{array}$ & $\begin{array}{r}82 \\
105 \\
82 \\
82\end{array}$ & $\begin{array}{l}\bar{Z} \\
\overline{-}\end{array}$ & $\begin{array}{l}-6 \\
-\end{array}$ & $\begin{array}{l}\overline{2} \\
\bar{\uparrow} \mathrm{s}\end{array}$ & $\begin{array}{r}24 \\
3 \\
2 \\
-\end{array}$ & $\begin{array}{r}40 \\
30 \\
2 \\
-\end{array}$ & $\begin{array}{l}20 \\
40 \\
-\end{array}$ & $\begin{array}{r}9 \\
15 \\
5 \\
\frac{1}{\uparrow} \mathrm{R}\end{array}$ & $\begin{array}{r}3 \\
4 \\
21 \\
2\end{array}$ & $\frac{2}{18}$ & $\begin{array}{r}\frac{2}{29} \\
3\end{array}$ & $\frac{-}{23}$ & $\frac{-}{4}$ & $\frac{\bar{z}}{32}$ & $\frac{-}{31}$ & $\overline{\overline{2}}$ \\
\hline Haemophilus influenzae & $\begin{array}{l}\mathbf{R} \\
\mathbf{E} \\
\mathbf{C} \\
\mathbf{L}\end{array}$ & 36 & $\begin{array}{l}\bar{z} \\
\overline{-}\end{array}$ & $\begin{array}{l}E \\
-\end{array}$ & E & $\begin{array}{l}E \\
-\end{array}$ & $\begin{array}{r}-3 \\
3 \\
-\end{array}$ & $\bar{z}$ & $\frac{28}{\frac{7}{\uparrow s}}$ & $\frac{60}{3}$ & $\frac{9}{-}$ & $\begin{array}{c}3 \\
\frac{9}{3} \\
\uparrow R\end{array}$ & $\begin{array}{l}\overline{44} \\
19 \\
-\end{array}$ & $\begin{array}{l}\overline{44} \\
42 \\
11\end{array}$ & $\frac{\overline{ }}{\overline{11}}$ & $\frac{\overline{1}}{11}$ & $\overline{71}$ \\
\hline
\end{tabular}

Table I Sensitivity to rifampicin, clindamycin, lincomycin, and erythromycin of strains of common pathogenic bacteria recently isolated from clinical samples

${ }^{1} \mathrm{C}=$ clindamycin, $\mathrm{E}=$ erythromycin, $\mathrm{L}=$ lincomycin, $\mathbf{R}=$ rifampicin, arranged in order of diminishing sensitivity in vitro for each organism.

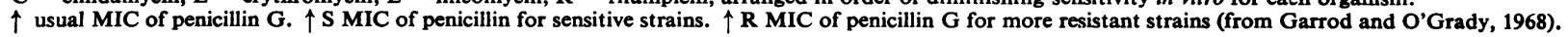


using a $2 \mu \mathrm{g}$ disc, highly sensitive Clostridium welchii had zones of 30 to $44 \mathrm{~mm}$ diameter, sensitive beta-haemolytic streptococci zones of 22 to $32 \mathrm{~mm}$ diameter, relatively less sensitive Haemophilus influenzae had zones of 0 to $14 \mathrm{~mm}$ diameter, and similarly less sensitive Streptococcus faecalis had zones of 0 to $12 \mathrm{~mm}$ diameter. All staphylococci had moderate zones with the exception of the only two resistant strains which had no zones. Table I shows the range of MICs for all these strains.

\section{CLINDAMYCIN}

There is good correlation between results of disc sensitivity testing and MICs. In our laboratory, beta-haemolytic streptococci, with MICs of 0.006 to $0 \cdot 12 \mu \mathrm{g} / \mathrm{ml}$, had zones around a $2 \mu \mathrm{g}$ disc of 17 to $28 \mathrm{~mm}$, with 32 out of 37 tests falling in the range 19 to $23 \mathrm{~mm}$. Sensitive Str. viridans and Str. pneumoniae had similar zone sizes. $\mathrm{Cl}$. welchii with MICs of less than $0.03 \mu \mathrm{g} / \mathrm{ml}$ had zones of 30 to 35 $\mathrm{mm}$, while those with MICs of 0.5 or $1 \mu \mathrm{g} / \mathrm{ml}$ had zones of 21 to $29 \mathrm{~mm}$. Many strains of $H$. influenzae, with MICs mostly above $4 \mu \mathrm{g} / \mathrm{ml}$, had no zones of inhibition, although nine out of 45 strains had zones of 8 to $13 \mathrm{~mm}$ in diameter. No strains of Str. faecalis, most of which had MICs above $32 \mu \mathrm{g} / \mathrm{ml}$, had zones. Sensitive Staph. aureus with MICs around $0.06 \mu \mathrm{g} / \mathrm{ml}$ had zones ranging from 19 to 27 $\mathrm{mm}$, while three resistant strains with MICs greater than $32 \mu \mathrm{g} / \mathrm{ml}$ had no zones.

\section{Determination of Bacteriostatic and Bactericidal Activity}

McCabe and Lorian (1968), Kunin, Brandt, and Wood (1969), Atlas and Turck (1968), and Arioli, Pallanza, Furesz, and Carniti (1967) have recently discussed the activity in vitro of rifampicin. Garrison, DeHaan, and Lawson (1968) and Phillips, Fernandes, and Warren (1970) have similarly reported studies on clindamycin.

\section{MINIMUM INHIBITORY CONCENTRATIONS}

For both antibiotics, MIC determinations are uncomplicated. With rifampicin, results are little affected by the addition of protein, $p \mathrm{H}$ makes little difference over a range $p \mathrm{H} 6-8$, and changes of inoculum size up to about $10^{6}$ organisms have little effect (McCabe and Lorian, 1968; Arioli et al, 1967). Clindamycin sensitivity is similarly little affected by these factors.

Table I shows our determinations of MJCs of rifampicin, clindamycin, lincomycin, and erythromycin for a series of common pathogens isolated recently in the Department of Clinical Microbiology, St. Thomas's Hospital. Average expected penicillin
MICs are also indicated, although they were not actually determined for these particular strains. Important organisms not included, but tested by others, and differences between our results and those of others are commented on below.

\section{Staph. aureus}

We examined 243 selected strains, 34 sensitive to all antibiotics, 43 resistant to penicillin only, 29 resistant to penicillin, streptomycin, and tetracycline, and 137 resistant to erythromycin (that is all the erythromycin-resistant staphylococci isolated in this laboratory in the past five years). Among the more resistant strains, 25 were also resistant to methicillin. Rifampicin is the most active drug: all strains are inhibited by $0.03 \mu \mathrm{g} / \mathrm{ml}$ or less, except two resistant strains with MICs of $8 \mu \mathrm{g} / \mathrm{ml}$ and $32 \mu \mathrm{g} / \mathrm{ml}$. Rifampicin was not used in St. Thomas's Hospital when these organisms were collected. As expected, clindamycin is more active than lincomycin, and is also more active than erythromycin. Among the 137 erythromycin-resistant strains, only three were resistant to clindamycin and lincomycin. Neither lincomycin nor clindamycin was much used when these strains were collected and therefore we have no information on the emergence of resistance noted by Geddes et al (1970). Many of the erythromycinresistant strains were isolated at a time when that antibiotic was fairly widely used, usually in combination with novobiocin (Ridley, 1966). On a weightfor-weight basis rifampicin is as active as penicillin $\mathrm{G}$ (against sensitive strains) and clindamycin is as active as cloxacillin.

\section{Staph. albus}

Published reports indicate that coagulase-negative staphylococci are generally as sensitive as Staph. aureus to both rifampicin and clindamycin.

\section{Beta-haemolytic streptococci}

The 43 strains examined included 18 group $A, 2$ group B, 16 group C, and 7 group G. None of the antibiotics are as active as penicillin $\mathbf{G}$ but all are highly effective in the order rifampicin, clindamycin, erythromycin, lincomycin. We did not encounter either erythromycin- or lincomycin/clindamycinresistant strains, although both have been reported, especially from burns units (Lowbury and Hurst, 1959; Kohn, Hewitt, and Fraser, 1968; Kohn and Evans, 1970).

Str. viridans and Str. pneumoniae

We tested 25 strains of Str. viridans and 27 pneumococci (only about half of each with rifampicin). Clindamycin, erythromycin, and rifampicin are all about as effective as penicillin. We did not see 


\begin{tabular}{llcc}
\hline Antibiotic & $\begin{array}{l}\text { Str. viridans from } \\
\text { Blood before Treatment }\end{array}$ & $\begin{array}{l}\text { Str. viridans from } \\
\text { Teeth after Penicillin }\end{array}$ & $\begin{array}{l}\text { Str. faecalis from } \\
\text { Blood before Treatment }\end{array}$ \\
\hline Penicillin & 0.001 & 0.3 & 2.5 \\
Cephaloridine & 0.005 & 0.3 & 2.5 \\
Vancomycin & 0.6 & 1.2 & 5.0 \\
Erythromycin & 0.03 & 0.03 & - \\
Clindamycin & 0.03 & 0.03 & 10.0 \\
Rifampicin & 0.03 & 0.03 & - \\
Streptomycin & 25.0 & 12.5 & 100 \\
Gentamicin & 10.0 & 25.0 & 10.0 \\
Kanamycin & 50.0 & 25.0 & \\
\hline
\end{tabular}

Table II Minimum inhibitory concentrations of nine antibiotics for streptococci isolated from blood and teeth in cases of subacute bacterial endocarditis

resistant pneumococci although they have been reported, almost always after treatment with either lincomycin (Dixon, 1967) or rifampicin (Citron and May, 1969).

A number of strains of streptococci isolated from patients with bacterial endocarditis have been examined in more detail. As an example of our results Table II shows MICs of a wide range of antibiotics for three streptococci, two of them Str. viridans isolated from the blood before treatment and from the teeth of the same patient after penicillin, and the third, Str. faecalis-like, isolated from the blood of another patient before treatment. When the first two strains are compared, it will be seen that the expected increase in penicillin resistance has occurred, and this has been accompanied by a very similar increase in cephaloridine resistance. However, MICs of clindamycin, rifampicin, erythromycin, and vancomycin, as well as gentamicin, kanamycin, and streptomycin, have remained unchanged. It is often suggested that these organisms are Str. faecalis-like in antibiotic sensitivity, but this is clearly untrue from these results, which are representative of a number that we have examined.

\section{Str. faecalis}

Neither lincomycin nor clindamycin has useful activity against Str. faecalis with MICs usually greater than $32 \mu \mathrm{g} / \mathrm{ml}$. Erythromycin is a little better than rifampicin, but neither drug has much to offer in the treatment of infections with this difficult organism.

\section{Cl. welchii}

We examined only 14 strains, all of which were sensitive to all three agents. Rifampicin is best and is as active as penicillin. Both clindamycin and lincomycin are generally more effective than erythromycin, but it is interesting that strains fell into two groups, one highly sensitive and the other somewhat less sensitive. Willis (personal communication) has found all of 161 strains of $\mathrm{Cl}$. welchii sensitive to clindamycin in disc sensitivity tests.

\section{Other Gram-positive bacilli}

Willis (personal communication) found all of 71 strains of $\mathrm{Cl}$. tetani sensitive to clindamycin, but among other Clostridia some were sensitive and some resistant. Bacillus anthracis and Corynebacterium diphtheriae are usually sensitive to both clindamycin and rifampicin (Garrison et al, 1968). Clindamycin is active against Actinomyces (Lerner, 1969) but neither clindamycin nor rifampicin seems active against Nocardia.

\section{Neisseria gonorrhoeae}

Both erythromycin and rifampicin are about as active as penicillin against 82 strains examined. Clindamycin, like lincomycin, is much less active.

\section{Neisseria meningitidis}

It has been reported that $N$. meningitidis is, like $N$. gonorrhoeae, sensitive to rifampicin (Deal and Sanders, 1969) and resistant to the lincomycins (McGehee et al, 1968).

\section{Haemophilus influenzae}

It is generally agreed that rifampicin is moderately active, erythromycin is less so, and lincomycin only weakly active but there is disagreement on the range of sensitivity of $\boldsymbol{H}$. influenzae to clindamycin. Garrison et al (1968), McGehee et al (1968), and Pelzl (1969) report MICs in the range found by us, but Oppenheimer and Turck (1968), Meyers, Kaplan, and Weinstein (1969), Geddes et al (1970), and Zinnemann and Fraser (1970) have found them considerably more sensitive. Until strains are exchanged and methods compared directly, the controversy will continue.

\section{Bacteroides}

Ingham, Selkon, Codd, and Hale (1970) have found Bacteroides fragilis sensitive to clindamycin, with MICs in the range 0.07 to $0.6 \mu \mathrm{g} / \mathrm{ml}$ and sensitive to rifamycin B (and thus, presumably, to rifampicin). Willis (personal communication) found five strains of Bacteroides melaninogenicus and 13 of 15 other 
Bacteroides species sensitive to clindamycin, using $2 \mu \mathrm{g}$ discs.

\section{Other Gram-negative bacilli}

Rifampicin was highly active against two strains of Pasteurella multocida tested by Arioli et al (1967). It also has considerable activity in vitro, unlike clindamycin, against a large number of other Gram-negative bacilli. Minimum inhibitory concentrations in the range $1-15 \mu \mathrm{g} / \mathrm{ml}$ are reported for Pseudomonas aeruginosa, Escherichia coli, Klebsiella-Enterobacter, Proteus, Salmonella, Shigella, and Brucella (Arioli et al, 1967; Atlas and Turck, 1968; McCabe and Lorian, 1968; Kunin et al, 1969). On this basis it is rather more active than ampicillin or cephaloridine.

\section{Mycoplasmata}

Clindamycin is active, though less so than erythromycin, against $M$. p.neumoniae, but unlike erythromycin it is active against $M$. hominis (Harwick and Fekety, 1969). Rifampicin has a very weak action on $M$. hominis (Harwick and Fekety, 1969).

\section{BACTERICIDAL PROPERTIES}

\section{Rifampicin}

If bactericidal concentrations (MBCs) of rifampicin are determined in liquid medium with a light inoculum, MBCs and MICs appear to be very close. If, however, heavier inocula are used, 'skip' tubes become common even in MIC determinations, that is, in a series of increasing concentrations of antibiotic, no growth occurs in some but does occur in occasional tubes containing more antibiotic. This is due to the presence of resistant mutants, found in a proportion of $1: 10^{6-7}$ in many strains of Staph. aureus, for example (McCabe and Lorian, 1968), a rate similar to that of resistance to fusidic acid, erythromycin, and streptomycin. However, the very low MBCs obtained with small inocula are also often false, as Baudens and Chabbert (1969) have demonstrated that rifampicin remains attached to cells on subculture and can only be removed by several washes in antibiotic-free medium. They have also shown that such antibiotic-free cells do not begin to multiply immediately but remain quiescent for several hours and then multiply at a normal rate -a phenomenon that they call 'bacteriopause'.

\section{Clindamycin}

There appear to be no problems in determining bactericidal levels of clindamycin, and MBCs are usually about 10 times the MICs.

\section{The Clinical Uses of Rifampicin and Clindamycin}

The review of antibacterial activity in vitro of these $\overrightarrow{\vec{F}}$ two antibiotics suggests that both deserve serious ? consideration for use against most Barber group 1 을 organisms, and that rifampicin should also be $\frac{\overline{\bar{N}}}{\bar{\rho}}$ considered in the treatment of infections due to a $\frac{\text { क }}{\sigma}$ wide range of Gram-negative organisms. However, $\stackrel{\mathbb{2}}{\circ}$ despite these encouraging results in vitro, the use of these drugs should be restricted for two reasons. $\vec{\circ}$ First, penicillin is almost always as active or more active in vitro, and we know the good clinical poten- $\vec{\omega}$ tial of penicillin. Therefore when penicillin is known to be highly effective and not to be clinically? contraindicated, for example by hypersensitivity, $\underset{\perp}{\sim}$ it should be preferred. The second reason is the emergence of resistance during treatment, almost $\vec{t}$ unknown with penicillin, but seen with clindamycin $\stackrel{\circ}{\circ}$ relatively uncommonly and with rifampicin so often as to make the antibiotic alone virtually useless. Unfortunately, clindamycin resistance seems to emerge more rapidly in erythromycin-resistant staphylococci in vitro (McGehee, Barrett, and $\vec{\theta}$ Finland, 1969).

Clindamycin has actually been used in a variety of infections due to sensitive organisms and has given, on the whole, very good results. Against Staph. aureus infections it has been at least as good as the penicillins for cellulitis, abscesses, and wound $\stackrel{\square}{\square}$ infections, as well as in more severe infections such $\underset{\Rightarrow}{\overrightarrow{0}}$ as osteomyelitis, pneumonia, and septicaemia (Daschner and Marget, 1969; Pelzl, 1969; Schlegel and Hieber, 1969; Kanee, 1969; Geddes et al, 1970). It appears to give results as good as lincomycin, and possibly better than the penicillins, in staphylococcaloㅇㅇ infections of bones and joints (Geddes et al, 1970). $\frac{\dot{\sigma}}{7}$ Clindamycin has also given results as good as penicillin or erythromycin in the treatment of $\delta$ respiratory tract infections due to Str. pyogenes, and in streptococcal cellulitis and pyoderma (Berman and Levine, 1969; Kanee, 1969; Lattanzi, Krosnick, Hurwitz, Goldstein, and Krassner, 1969). It has been used successfully in a variety of pneumococcal infections (Geddes et al, 1970). In the absence of O a clinical trial, its usefulness in the treatment of $N$ chronic bronchitis is difficult to assess, in spite of $\mathrm{W}^{\mathrm{W}}$ suggestions that both serum and sputum levels are adequate (Mitchell, 1970).

There remains a variety of infections for which $\frac{0}{\Phi}$ clindamycin deserves to be assessed, as, for example, $\stackrel{\oplus}{+}$ diphtheria, and Bacteroides infections, and in the $T$ prophylaxis of bacterial endocarditis, tetanus, and $\bar{O}$ gas gangrene.

In whatever situation it is used, one should be $\frac{O}{\otimes}$ prepared for the emergence of resistance during $\frac{\varrho}{\sigma}$ treatment-already reported with Staph. aureus, 
pneumococci, and beta-haemolytic streptococci. The more regular use of other antibiotics in combination might prevent this. It should replace lincomycin completely, except when injections are needed.

Rifampicin is more difficult to assess from the few reports of clinical uses. The strikingly successful use is in tuberculosis, for which it is possibly the most active available drug, always used in combination with other drugs. We must ensure that this position is not jeopardized by its indiscriminate use in other conditions.

When rifampicin is used, it should almost always be used in combination with at least one other drug such as erythromycin, clindamycin, fusidic acid, or an aminoglyoside (Bals and Filipescû, 1969). In a small reported series Jensen (1967 and 1968) describes good clinical results in severe staphylococcal disease, but rifampicin resistance emerged in a number of cases in spite of the addition of fusidic acid or novobiocin. The point should not be missed, however, that clinical effects were good in infections with organisms resistant to most of the usual antistaphylococcal drugs. In addition to Jensen's report, there are brief reported series of cases of less serious staphylococcal disease and of respiratory tract infection that appear to have responded favourably (Brickner, 1969).

Gonorrhoea has also been treated with rifampicin, with a $10 \%$ failure rate in one series of patients given a single oral dose of $900 \mathrm{mg}$. Increased doses might cut down failure rate but better results can be obtained at the moment with several drugs. The emergence of resistance was not considered in this report (Willcox, Morrison, and Cobbold, 1970).

The worst clinical results are reported when rifampicin has been used to treat infections due to Gram-negative organisms-mostly of the respiratory and urinary tracts. For example, Citron and May (1969) treated five chronic bronchitics with rifampicin alone: all failed to respond and rifampicinresistant $H$. influenzae and pneumococci were isolated after, but not before, treatment. Using rifampicin for the treatment of urinary tract infection, Murdoch, Speirs, Wright, and Wallace (1969) report clinical failures in 11 of 19 patients given $900 \mathrm{mg}$ daily in divided doses, and relapse in the remaining eight, and Atlas and Turck (1968) report 23 failures out of 27 patients treated with $300 \mathrm{mg}$ three times daily with large increases of antibiotic resistance in surviving organisms. Brickner (1969) also reports many failures. On the other hand, Trafton and Lind (1970) have recently reported a strikingly different situation. They treated 57 patients with genito-urinary infection, both acute and chronic, who had failed to respond to a variety of other antibiotics, using a dose of $300 \mathrm{mg}$ three times daily. Immediate results, both clinical and bacteriological, were on the whole good, but details on follow up are not included.

In one situation, tuberculosis apart, rifampicin seems to be a better drug than any, and this is in the clearing of meningococcal throat carriers. Deal and Sanders (1969) have reported from Florida that a dose of $600 \mathrm{mg}$ per day for four days results in a permanent reduction of carriage rate by $93.3 \%$ and that no resistant organisms have emerged. Rifampicin is almost as good as was sulphadiazine when meningococci are fully sensitive, and is much more effective than any other agent. The results of more widespread use are awaited with interest.

\section{Conclusion}

Rifampicin and clindamycin are two non-toxic, orally administered antibiotics that have in common an antibacterial spectrum covering Gram-positive organisms. Both can be considered as alternatives to penicillin which should be used whenever possible. In addition rifampicin has high antimycobacterial activity, particular activity against Neisseria meningitidis, and unstable activity on many Gramnegative bacilli. Because of the likelihood of the emergence of resistance both rifampicin and clindamycin should probably always be used in combination with other antibiotics. Clindamycin already has a well assured clinical place in the treatment of infection due to Gram-positive organisms, but rifampicin should at the moment be reserved for the treatment of tuberculosis, for the treatment of meningococcal carriers, and for serious sepsis, particularly staphylococcal, due to organisms resistant to conventional drugs.

I thank Mr Rosario Fernandes and Miss Christine Warren for technical assistance, and Dr C. Granger of Lepetit Pharmaceuticals Ltd and Dr V. Whitmarsh of Upjohn Ltd for providing reprints of published material. I also thank Lepetit Pharmaceuticals (UK) Ltd and Upjohn Ltd for generous financial support for the studies at St Thomas's Hospital.

\section{References}

Acocella, G., Nicolis, F. B., and Lamarina, A. (1967). A study on the kinetics of rifampicin in man. Vth International Congress of Chemotherapy, Vienna, Suppl., 1, 87-93.

Arioli, V., Pallanza, R., Furesz, S., and Carniti, G. (1967). Rifampicin: a new rifamycin. I. Bacteriological studies. ArzneimittelForsch., 17, 523-529.

Atlas, E., and Turck, M. (1968). Laboratory and clinical evaluation of rifampicin. Amer. J. med. Sci., 256, 247-254.

Bals, M. G., and Filipescû, S. (1969). The antistaphylococcal activity of rifampicin. Arzneimittel-Forsch., 19, 1285-1287.

Barber, M. (1966). Antibacterial activity of antibiotics. In The Therapeutic Use of Antibiotics in Hospitals, p. 28, by M. Ridley, and I. Phillips. Livingstone, Edinburgh. 
Baudens, J. G., and Chabbert, Y. A. (1969). Rifampicine: bactéricidie et bactériopause. Path. et Biol., 17, 391-397.

Berman, J. D., and Levine, M. K. (1969). The efficacy of clindamycin in beta-hemolytic streptococcal infections of the upper respiratory tract. J. med. Ass. Georgia, 58, 155-157.

Brickner, P. W. (1969). Rifampin: clinical studies with a new antibiotic. J. clin. Pharmacol., 9, 243-250.

British Medical Associtation (1970), Today's Drugs, New Series, I, p. 33. B.M.A., London

Brodasky, T. F., Argoudelis, A. D., and Eble, T. E (1968) The characterisation and thin-layer chromatographic quantitation of the human metabolite of 7-deoxy-7(S) chlorolincomycin (U-21, 251F). J. Antibiot. (Tokyo), 21, 327-333.

Cimino, J. E., and Tierno, P. M. (1969). Hemodialysis properties of clindamycin (7-choro-7-deoxylincomycin). Appl. Mircobiol., $17,446-448$

Citron, K. M., and May, J. R. (1969). Rifamycin antibiotics in chronic purulent bronchitis. Lancet, 2, 982-983.

Curci, G., Ninni, A., and Iodice, F. (1969). Quelques considérations sur la pharmacocinétique de la rifampicine. Acta tuberc. pneumol. belg., 60, 276-287.

Daschner, F., and Marget, W. (1969). Untersuchungen zur Anwedung des 7-chlor-7-desoxylincomycin in der Kinderheilkunde. Arzneimittel-Forsch., 19, 1003-1006.

Dixon, J. M. S. (1967). Pneumococcus resistant to erythromycin and lincomycin. Lancet, 1, 573.

Deal, W. B., and Sanders, E. (1969). Efficacy of rifampicin in treatment of meningococcal carriers. New Engl.J. Med., 281, 641645.

Furesz, S. (1969). Recent investigations on the biological properties of rifampicin. Acta tuberc. pneumol. belg., 60, 266-269.

Furesz, S., Scotti, R., Pallanza, R., and Mapelli, E. (1967). Rifampicin a new rifamycin. III. Absorption, distribution and elimination in man. Arzneimittel-Forsch., 17, 534-537.

Garrison, D. W., DeHaan, R. M., and Lawson, J. B. (1968). Comparison of in vitro antibacterial activities of 7-chlor-7deoxylincomycin, lincomycin, and erythromycin. Antimicrob. Agents Chemother. 1967, 7, 397-400.

Garrod, L. P., and O'Grady, F. (1968). Antibiotic and Chemotherapy, 2nd ed., p. 258. Livingstone, Edinburgh.

Geddes, A. M., Bridgwater, F. A. J., Williams, D. N., Oon, J., and Grimshaw, G. J. (1970). Clinical and bacteriological studies with clindamycin. Brit. med. J., 2, 703-704.

Hartmann, G., Honikel, K. O., Knüsei, F., and Nüesch, J. (1967). The specific inhibition of DNA-directed RNA synthesis by rifamycin. Biochim. biophys. Acta (Amst), 147, 843-844.

Harwick H. J., and Fekety, F. R., Jr., (1969). The antibiotic susceptibility of Mycoplasma hominis. J. clin. Path., 22, 483-485.

Ingham, H. R., Selkon, J. B., Codd, A. A., and Hale, J. H. (1970). The effect of carbon dioxide on the sensitivity of Bacteroides fragilis to certain antibiotics in vitro. J. clin. Path., 23, 254-258.

Jensen, K. (1967). Combination therapy of infections caused by methicillin-resistant staphylococci with rifampicin plus fusidic acid or novobiocin. Vth International Congress of Chemotherapy, Vienna, 1, 783-784.

Jensen, K. (1968). Methicillin-resistant staphylococci (Letter). Lancet, $2,1078$.

Jouhar, A. J. (1968). The rifamycin antibiotics-in retrospect and prospect. J. Therap. clin. Res., 2, 17-21.

Kanee, B. (1969). Clindamycin in the treatment of pyoderma. Appl. Ther., 11, 482-483, 497.

Kohn, J., Hewitt, J. H., and Fraser, C. A. M. (1968). Group A, streptococci resistant to lincomycin (Letter). Brit. med. J., 1, 703.

Kohn, J., and Evans, A. J. (1970). Group A streptococci resistant to clindamycin. Brit, med. J., 2, 423.

Kunin, C. M., Brandt, D., and Wood, H.(1969). Bacteriologic studies of rifampin, a new semisynthetic antibiotic. J. infect. Dis., 119, 132-137.

Lancet (1969). New drugs against tuberculosis. 1, 1081-1082.

Lattanzi, W. E., Krosnick, M. Y., Hurwitz, S., Goldstein, P., and Krassner, L. (1969). The treatment of beta-haemolytic streptococcal throat infections with clindamycin. Int. med. Dig., Oct., 29-31.

Lerner, P. I. (1969). Susceptibility of Actinomyces species to lincomycin and its 7-halogenated analogues. Antimicrob. Agents Chemother, 1968, p. 461-464.

Lowbury, E. J. L., and Hurst, L. (1959). The sensitivity of staphylococci and other wound bacteria to erythromycin, oleandomycin and spiramycin. J. clin. Path., 12, 163-169.

McCabe, W. R., and Lorian, V. (1968). Comparison of the antibacterial activity of rifampicin and other antibiotics. Amer. J. med. Sci., 256, 255-265.

McGehee, R. F., Jr., Barrett, F. F., and Finland, M. (1969). Resistance of Staphylococcus aureus to lincomycin, clinimycin, and erythromycin. Antimicrob. Agents Chemother., 1968, 8, 392-397.

McGehee, R. F., Jr., Smith, C. B., Wilcox, C., and Finland, M. (1968). Comparative studies of antibacterial activity in vitro and absorption and excretion of lincomycin and clinimycin. Amer. J. med. Sci., 256, 279-292.

Magerlein, B. J., Birkenmeyer, R. D., and Kagan, F. (1967). Chemical modification of lincomycin. Antimicrob. Agents Chemother. 1966, 6, 727-736.

Meyers, B. R., Kaplan, K., and Weinstein, L. (1969). Microbiological and pharmacological behavior of 7-chlorolincomycin. Appl. Microbiol., 17, 653-657.

Mitchell, A. A. B. (1970). Chemotherapy of bronchitis (Letter). Brit. med. J., 2, 481-482.

Murdoch, J. McC., Speirs, C. F., Wright, N., and Wallace, E. T. (1969). Rifampicin (Letter). Lancet, 1, 1094.

Oppenheimer, S., and Turck, M. (1968). Laboratory and clinical evaluation of 7-chloro-7-deoxylincomycin. Amer. J. med. Sci., 256, 314-321.

Pelzl, H. (1969), Klinische Erfahrungen bei der Behandlung chirurgischer Infektionen mit einem neuen LincomycinDerivat. Arzneimittel-Forsch., 19, 117-119.

Phillips, I., Fernandes, R., and Warren, C. (1970). In vitro comparison of erythromycin, lincomycin, and clindamycin. Brit. med. J., 2, 89-90.

Ridley, M. (1966). In M. Ridley, and I. Phillips. The Therapeutic Use of Antibiotics in Hospitals, p. 3. Livingstone, London.

Schlegel, D., and Hieber, E. (1969). Practical experiences with 7-chloro-7-deoxylincomycin in jaw surgery. Zahnärztl. Prax., $20,37-40$.

Sensi, P. (1969). Structure-activity relationships of rifamycin derivatives. Acta tuberc. pneumol. belg., 60, 258-265.

Spring, P. (1968). The pharmacokinetics of Rimactane in patients with impaired liver and kidney function. In Symposium on Rimactane, Basle, pp. 32-34.

Sun, F. F. (1970). Disposition of clindamycin in rat and dog. Fed. Proc., 29, 677.

Trafton, H. M., and Lind, H. E. (1970). The treatment of urinary tract infections with a new antibiotic. Clin. Med., 77 (3), 30-33.

Verbist, L. (1969). Rifampicin blood levels in man. Acta tuberc. pneumol. belg., 60, 288-298.

Wagner, J. G., Novak, E., Patel, N. C., Chidester, C. G., and Lummis, W. L. (1968). Absorption, excretion and half-life of clinimycin in normal adult males. Amer. J. med. Sci., 256, 25-37.

Weisblum, B., and Davies, J. (1968). Antibiotic inhibitors of the $\mathcal{O}$ bacterial ribosome. Bact. Rev., 32, 493-528.

Willcox, R. R., Morrison, E. D., and Cobbold, R. J. C. (1970). Rifa- O mpicin (Rimactane) in the treatment of gonorrhoea. Brit. J. N vener. Dis., 46, 145-148.

Zinnemann, K., and Frazer, J. (1970). Chemotherapy of bronchitis (Letter). Brit. med. J., 2, 481. 롱

$\rightarrow$

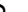

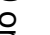
융 